\title{
Effect of Hexanal Vapour on Postharvest Quality and Shelf Life of Banana var. Grand Naine
}

\author{
T. Ashwini ${ }^{1 *}$, S. Ganapathy ${ }^{1}$, K.S. Subramanian ${ }^{2}$, C. Indu Rani ${ }^{1}$ and \\ G. Guru Meenakshi ${ }^{3}$ \\ ${ }^{1}$ Department of Food and Agricultural Process Engineering, ${ }^{2}$ Department of Nano Science \& \\ Technology, ${ }^{3}$ (FSN), Postharvest Technology Centre, AEC \& RI, Tamil Nadu Agricultural \\ University, Coimbatore - 641003, Tamil Nadu, India \\ *Corresponding author
}

A B S T R A C T

Keywords

Hexanal vapour,

Postharvest treatment,

Banana, Physicochemical

changes, Banana quality

Article Info

Accepted:

20 January 2018

Available Online:

10 February 2018
Banana fruit were exposed to hexanal vapour at 600,900 and $1200 \mathrm{ppm}$ for two and four $\mathrm{h}$ at $27 \pm 2^{\circ} \mathrm{C}$. Fruits were then stored at $27 \pm 2{ }^{\circ} \mathrm{C}$ with $65-75 \%$ relative humidity and latter assessed for quality. The rate of respiration, increase in TSS and loss of firmness were affected negatively by hexanal vapour treatment. Changes in the peel colour were also slowed compared to untreated fruits. The fruits treated with $1200 \mathrm{ppm}$ hexanal vapour for $2 \mathrm{~h}$ and $4 \mathrm{~h}$ exposure recorded a maximum shelf life of 18 days, whereas untreated fruits had a shelf life of 8 days only. Thus application of hexanal vapour was an effective technology for ripening inhibition and quality maintenance of Grand Naine banana.

\section{Introduction}

India is the largest producer of banana in the world followed by China, Philippines Ecuador and Brazil. Banana production in India constitutes $38 \%$ of the total fruit production. The total production of banana is 27.05 million tonnes from 0.77 million ha (AGRISTAT, 2014). Despite being world's largest producer, India contributes only 0.2 per cent of the total banana export in the world which is marginally low (FAOSTAT, 2013). The total postharvest losses of major agricultural products in India are estimated to be Rs. 44,000 crores, out of which the losses from fruits and vegetables accounts for Rs. 14,000 crores (Nanda et al., 2012).

There are several causes of postharvest losses, including increased respiration rate, ethylene production, physiological disorders and general senescence. But the excess of ethylene production during ripening is mainly responsible for higher postharvest losses in bananas (Sisler and serek, 1997). Commercially, once bananas are induced to ripen with exogenous ethylene their marketing life is only about $3-5 \mathrm{~d}$, depending on the 
ethylene treatment conditions and the storage temperature after the treatment. In order to extend the shelf life of bananas, the action or synthesis of ethylene must be inhibited or delayed. Recently, fumigation using 1Methylcyclopropene (1-MCP) gas to control ripening has been applied for extending the shelf life and quality of food products (Pelayo et al., 2003).

Hexanal is one such compound which is considered as GRAS for enhancing the shelf life of fruits and vegetables (Generally Recognized as Safe). It is a precursor to the formation of alcohols and esters that produce aroma. Hexanal is released when plant is wounded. It is reported as an antifungal agent to the species namely B. cinerea, P.expansum, C.acutatum (Song et al., 1996 and Fan et al., 2006). In addition to that, hexanal is a good inhibitor of Phospholipase D activity by degrading membrane during ripening process.

It is used for pre or post-harvest application by combining with EFF (Enhanced Fresh Formulation) to enhance the shelf life of fruits such as banana, apple, grapes, strawberry and sweetcherry, pear, tomato, broccoli, raspberry, peach and fresh cut vegetable (cauliflower, carrot, cucumber etc). It delays senescence in carnations, roses and chrysanthemums (Paliyath and Subramanian, 2008). Due to inhibitor of Phospholipase D enzyme which plays important role in senescence of fruits, so it is important to determine the effect of postharvest application of hexanal vapour on the quality of banana var. Grand Naine to extend the shelf life of the fruits.

\section{Materials and Methods}

\section{Raw material}

Bananas were harvested from the orchard of Tamil Nadu Agricultural University, Coimbatore. Bananas $(3 \mathrm{~kg})$ were arranged in
578 × 385 × $210 \mathrm{~mm}$ size of 41L Capacity crates with paper in between and also to avoid mechanical damage. Crates were transported to Nano Science and Technology Centre, Tamil Nadu Agricultural University, Coimbatore, and kept in cold store at $10^{\circ} \mathrm{C}$ to remove field heat and used for post-harvest hexanal vapour treatment.

\section{Cleaning}

Bananas were sorted by hand to eliminate the damaged fruit and to ensure uniformation in the sample for experimentation. Fruits were treated with $100 \mathrm{nLL}^{-1}$ sodium hypochlorite solution for 2 min for disease control and left to dry prior to treatment. Air dried fruits were selected for vapour treatment.

\section{Post-harvest hexanal vapour treatment}

Required quantity of hexanal $(3.35,5.03$ and, $6.7 \mu \mathrm{l})$ was taken in petri plates to attain three concentration such as $600\left(\mathrm{~T}_{1}\right), 900\left(\mathrm{~T}_{2}\right)$ and $1200\left(\mathrm{~T}_{3}\right) \mathrm{ppm}$, placed on petri plate holder in an acrylic rectangular vapour chamber (Fig. $1)$. The chamber is of $450 \times 200 \times 300 \mathrm{~mm}$ dimension with opening at the top to keep fruits and provided petri plate holder at the top left inside the chamber to allow the hexanal liquid to evaporate. The chamber has 27 ports for drawing gas samples and ports are covered with septum on all sides to draw the gas samples for analysis through Gas Chromatography and Mass Spectrometry (GCMS). In this method, bananas were exposed for $2 \mathrm{~h}$ and $4 \mathrm{~h}$ after which they were packaged in carton box and shelf life studies were conducted at ambient temperature.

\section{Method to assess quality of bananas}

\section{Initial quality analysis}

For initial analysis (day 0) six banana fingers were analyzed for physiological quality 
indicators such as firmness, respiration rate, physiological loss in weight, peel colour index and overall appearance. Three replicates of measurement of quality attributes were made and the mean initial values were recorded. The following parameters were studied in three days of intervals in order to determine the optimum hexanal vapour concentration to extend the shelf life of banana.

\section{Physiological Loss in Weight (PLW) (\%)}

Physiological loss in fruit weight was expressed in percentage in comparison with the initial weight.

Physiological loss in weight $(\%)=$

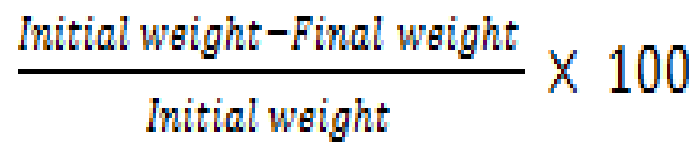

\section{Firmness}

The firmness of banana fruits were measured using a texture analyzer (Model TA-XT2 Stable Micro Systems). Firmness of the fruits was measured using a $2 \mathrm{~mm}$ diameter stainless steel probe, penetrating $10 \mathrm{~mm}$ into sample. The test was performed at a test speed of 1 $\mathrm{mms}^{-1}$ with a trigger force of $10.01 \mathrm{~N}$. The test was performed on whole unpeeled bananas at two points. Three fingers of bananas per replicates were used to perform the firmness test. The maximum force $(\mathrm{N})$ obtained during probe travel was used as a measure of firmness.

\section{Respiration rate}

Respiration rate of the fruits were measured in terms of carbon dioxide concentration. For the measurement, three fruit per treatment were weighed and individually placed in a glass container of $7 \mathrm{~L}$ volume and sealed with a lid. The free volume of the glass container was determined by deducting the volume of banana fruit form the total volume of the glass container. After $1 \mathrm{~h}$, gas samples were drawn from the glass container through silicon rubber septum using syringe and carbon-di-oxide concentration was measured out using a $\mathrm{CO}_{2}$ gas analyser (Model Checkmate 3 MAP Dan Sensor, Denmark). The Respiration rate was expressed in $\mathrm{mL} \mathrm{kg}^{-1} \mathrm{~h}^{-1}$.

\section{Total Soluble Solids}

Three fruits were selected randomly and pulped using pestle and mortar. Fruit pulp was filtered through muslin cloth and a drop of filtrate was taken to determine the total soluble solids (TSS) using hand refractometer (Make, Erma), and TSS was expressed as ${ }^{\circ}$ Brix (Ranganna, 1995).

\section{Peel colour index}

The rate of banana ripening from green to yellow was determined for each individual fruit, by using a colour index chart as described by Dole add year by kt file Europe. A numerical value from (1 to 7) was given to each sample based on the color, and average was calculated for results. The color scale was determined as followings. 1- green, 2 - more green than yellow, 3- green-yellow (50 -50 $\%), 4$-more yellow than green, 5 - yellow with green tips, 6 - completely yellow, and 7 yellow with brown spots.

\section{Overall appearance}

The visual quality of the bananas were determined based on hedonic scale as detailed below; $1=$ inedible; $2=$ limit of usability; $3=$ limit of marketability; $4=$ very good and $5=$ excellent. The scores of 3 banana fingers per replicates were given based on color, visual structural integrity, and general visual appeal (Vilas-Boas and Kader, 2006). 


\section{Statistical analysis}

Experiments were laid out using a Factorial Completely Randomized Design (FCRD). Data were analyzed by analysis of variance (ANOVA). Statistical analysis was carried out using the AGRES system.

\section{Results and Discussion}

\section{Shelf life}

The shelf life of banana exposed for $2 \mathrm{~h}$ and 4 $\mathrm{h}$ to hexanal vapour was observed. In this study banana fruits were allowed to move form stage 2 of ripening to stage 7 . It was observed that exposing banana to $2 \mathrm{~h}$ of hexanal vapour at $1200 \mathrm{ppm}$ had a shelf life of $18 \mathrm{~d}$ at $27 \pm 2^{\circ} \mathrm{C}$ whereas a $4 \mathrm{~h}$ exposure resulted in a shelf life of only $12 \mathrm{~d}$ (Fig. 2.) This could be due to Saturation of hexanal vapour attained by almost $2 \mathrm{~h}$ then it binds the Phospolipase-D enzyme and slowdown the ripening of bananas. At the $4 \mathrm{~h}$ of exposure due to long duration time in closed condition more condensation occurs on the walls of the chamber, and leads to microbial spoilage with respect to storage days. Increase in concentration of hexanal vapour with optimum treatment condition increases the shelf life of fruits and vegetables (Paliyath 2008).

\section{Physiological loss in weight (\%)}

The percentage increase in physiological loss of weight of fruits with storage period was observed (Fig. 3). Hexanal treated fruits at $1200 \mathrm{ppm}$ concentration showed reduced weight loss compared to $0 \mathrm{ppm}, 600 \mathrm{ppm}, 900$ ppm hexanal vapour treatments. The results obtained are in agreement with the findings of Jeong, et al., (2002); Manenoi, et al., (2007); Shiga, et al., (2009); Wills and $\mathrm{Ku},(2002)$; and
Colelli, et al., (2003). The reason for weight loss during ripening is due to high energy is required to run the process; hence, starch is converted into sugar and used as energy. This study indicated that the postharvest application of hexanal vapour had significant influence on the reduction of weight loss of banana fruits.

\section{Firmness}

Figure 4 shows the effect of different concentration of hexanal vapour treatments on maintaining firmness in bananas. As the bananas ripen they tend to soften more, especially when they move from climacteric phase to post climacteric phase. As the fruits were getting softer, it required less penetration force. An initial average external firmness of $19.37 \mathrm{~N}$ was noted for the fruits on day 0 , which dropped to $9.75 \mathrm{~N}$ for hexanal vapour treated samples, and $19.75 \mathrm{~N}$ to $8.32 \mathrm{~N}$ for control after 9 days. After 9 days it dropped down further to nearly $15.86 \mathrm{~N}$ for hexanal treated sample. Overall fruits treated with $1200 \mathrm{ppm}$ found to be best. Significant difference $(\mathrm{p}<0.01) 0$ between exposure time and concentration observed by statistical analysis throughout the storage period. This result was in agreement with the studies reported by Fan et al., 2000; Feng, et al., 2000; Pelayo, et al., 2003; Lohani, et al., 2004; Bassetto, et al., 2005.

\section{Respiration rate}

Figure 5 shows the effect of hexanal on the respiration rate of bananas. The highest respiration rate was observed on the third day of the treatment and similar responses were observed for the controls. Throughout the storage periods, significant difference was found in respiration rate of fruits treated with hexanal vapour and fruits without treatment. 
Fig.1 Acrylic chamber with banana

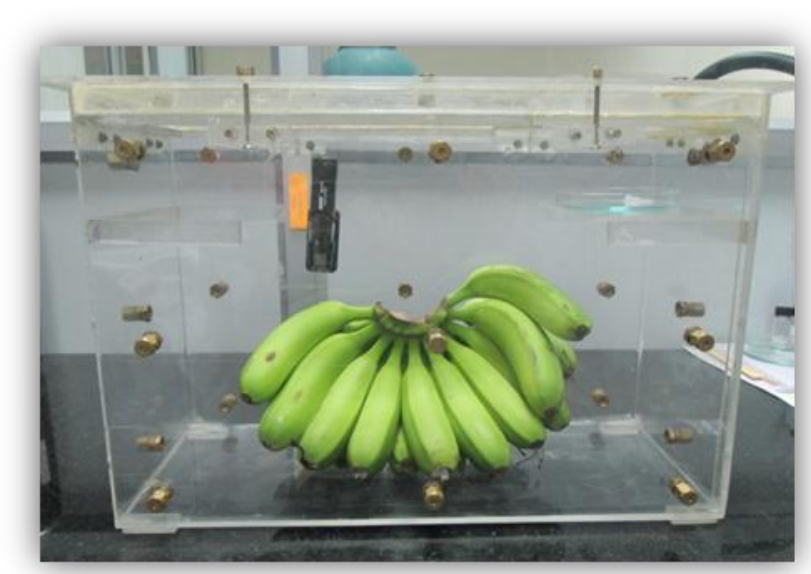

Fig.2 Effect of hexanal vapour on shelf life of banana at different exposure time ( 2 and $4 \mathrm{~h})$

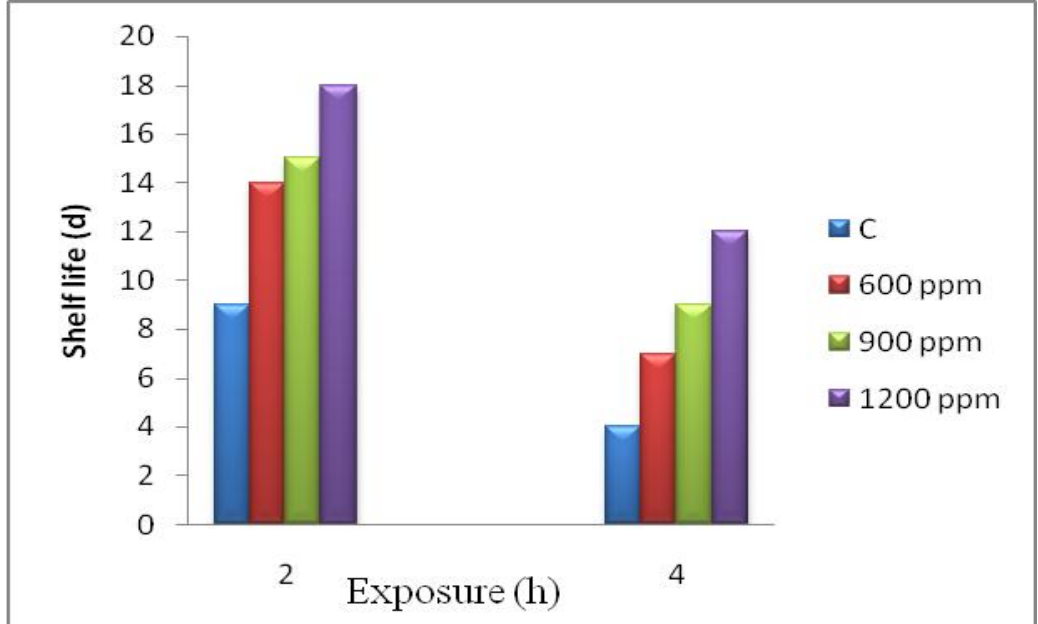

Fig.3 Effect of hexanal vapour treatment on PLW (\%) of banana at different exposure time (2 and $4 \mathrm{~h})$

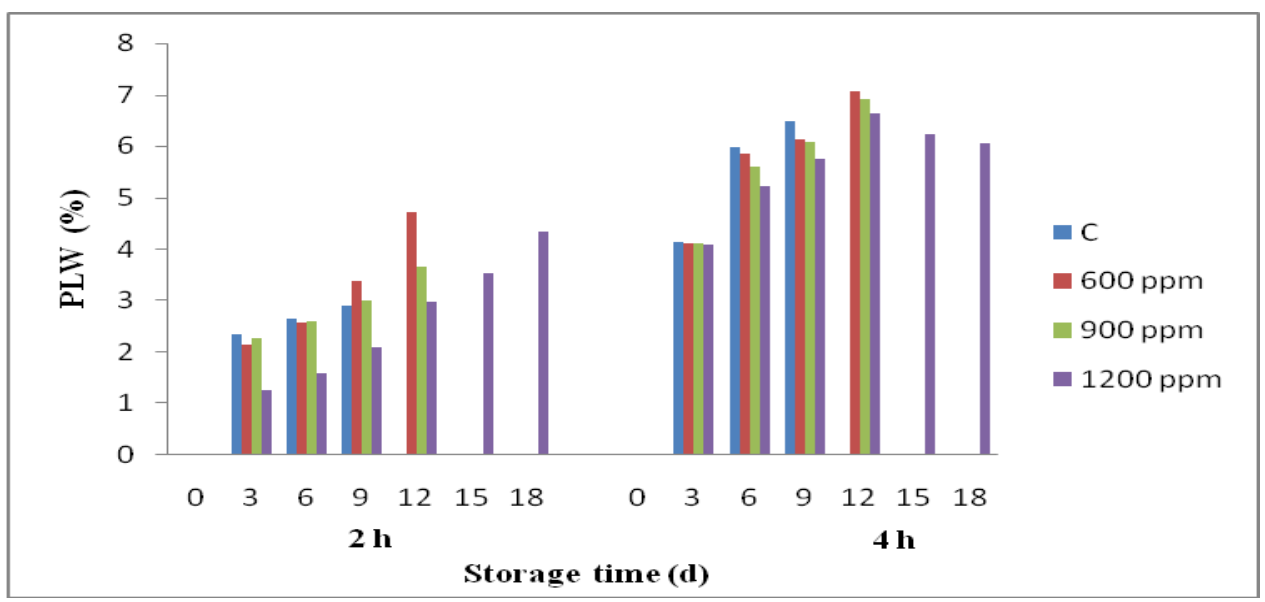


Fig.4 Effect of hexanal vapour on firmness (N) of bananas at different exposure time ( 2 and $4 \mathrm{~h})$

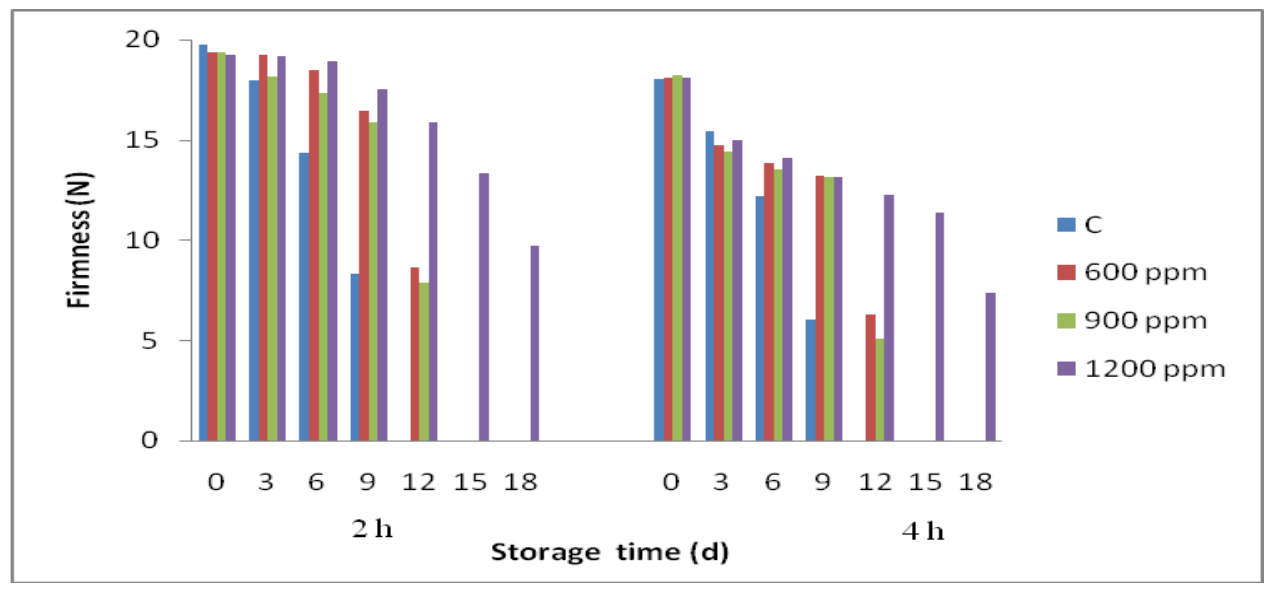

Fig.5 Effect of hexanal vapour on respiration rate $\left(\mathrm{ml} \mathrm{kg}^{-1} \mathrm{~h}^{-1}\right)$ on Banana at different ( 2 and $\left.\mathrm{h}\right)$ exposure time

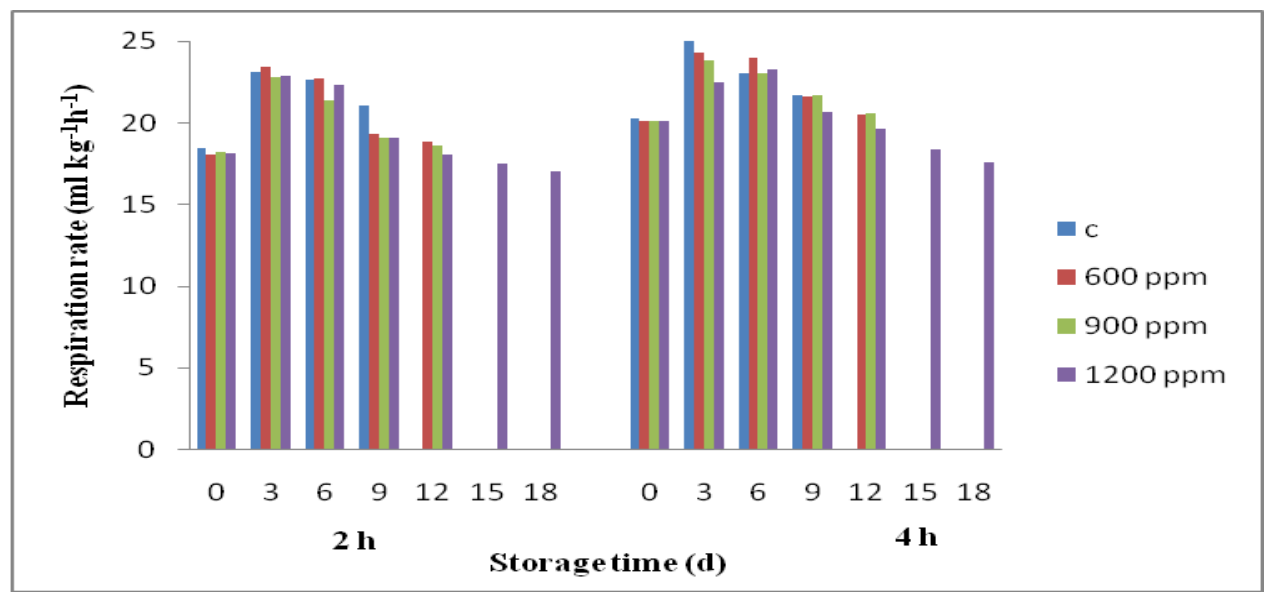

Fig.6 Effect of hexanal vapour on TSS ( ${ }^{\circ}$ Brix) of Banana at different exposure time ( 2 and $4 \mathrm{~h}$ )

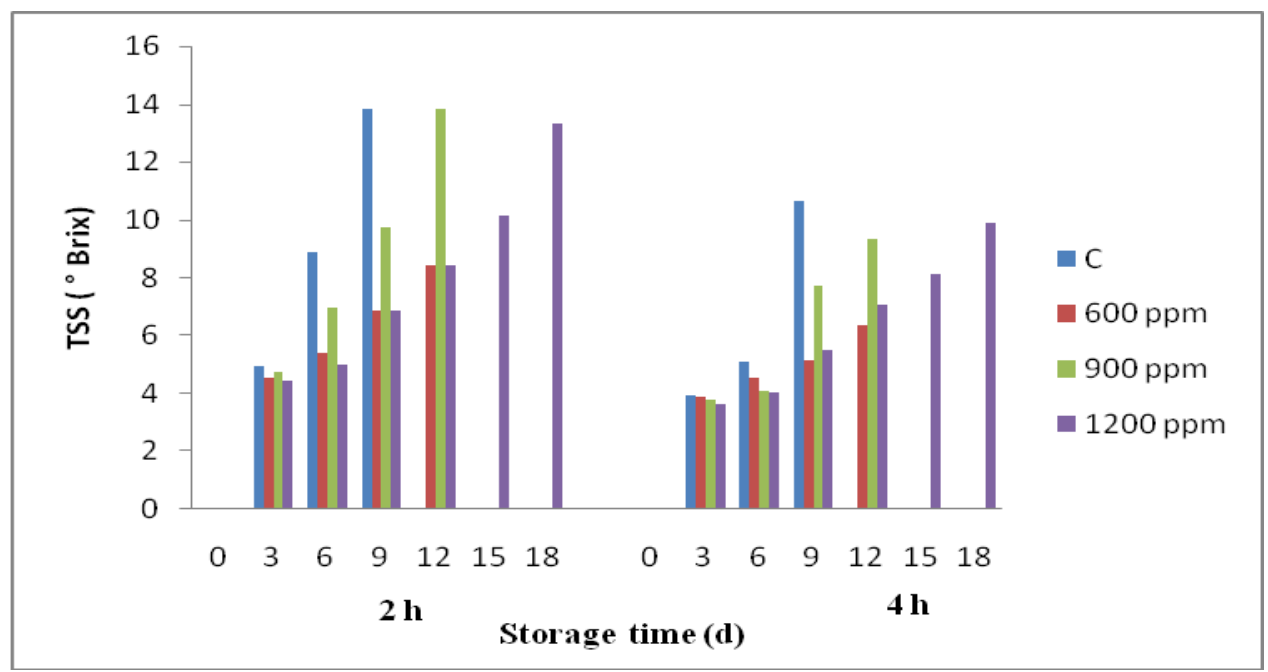


Fig.7 Effect of hexanal vapour on peel color of Banana at different exposure time (2 and $4 \mathrm{~h}$ )

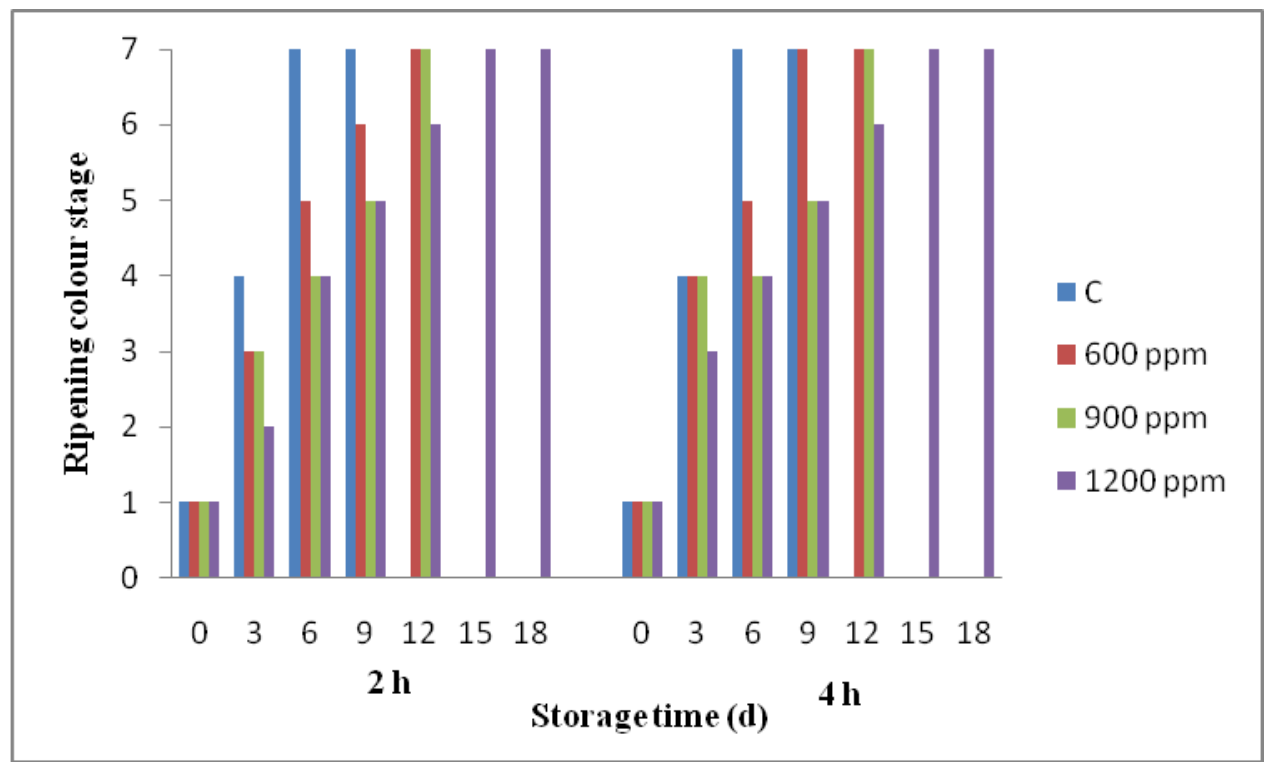

In this study, the climacteric rise in respiration rate was accompanied by a rapid change in colour from green to yellow. In each of these treatments stage 5 was reached at the climacteric peak of respiration rate. In untreated fruit, the rate of respiration remained high throughout storage. The rate of respiration was lower in hexanal treated banana than in untreated banana (Golding et al., 1998, 1999; Pathak et al., 2003; Pelayo et al., 2003; Lohani et al., 2004).

\section{Total soluble solids (TSS)}

As the banana starts ripening, the TSS content increases due to breakdown of starch. In this study, a significant difference was observed in TSS content of fruits treated with hexanal vapour and without any hexanal vapour treatment. At the $9^{\text {th }}$ day, the TSS content of fruits treated with $1200 \mathrm{ppm}$ hexananal vapour concentration for $2 \mathrm{~h}$ ranged between $6.86^{\circ}$ brix, whereas for control fruits it was found to be $13.85^{\circ}$ brix (Fig. 6). This shows that control samples were already at an advanced stage of ripening compared to treated hexanal vapour samples. These results implied that hexanal vapour treatments were effective to delay breakdown of starch content, which is one of the ripening indicator for banana. Similar results were reported by Krammes et al., (2003), Mir et al., (2004), Opiyo and Ying (2005) for tomato.

\section{Peel colour index}

The peel colour index of the banana fruits treated with hexanal vapour and without Hexanal vapour, using the banana colour chart (Fig. 7). Peel color index using the banana color chart indicated that there was a significant difference in the color of the hexanal vapour treated sample and the sample without any treatment. It is clear from Figure 7 that there is a definite effect of hexanal vapour on peel color of banana, even at a partially ripened stage.

For hexanal vapour treatment given at ripening color stage 3,1200 ppm for $2 \mathrm{~h}$ maintained ripening color stage 3 for the first five days, and then it had slowly started turning yellow after that. It reached stage 7 on the $15^{\text {th }}$ day of storage. Whereas the fruit in control started turning yellow from the $3^{\text {th }}$ day of treatment and it reached to stage 7 on the 
$6^{\text {th }}$ day of the experiment for the same concentration and exposure time. Similar studies were reported by Mir et al., (2001), Jiang et al., (2003), Jayanthy et al., (2004), and Hershkovitz et al., (2005).

\section{Overall appearance}

Bananas treated with hexanal vapour did not get the visual score 1 (inedible) on $7^{\text {th }}$ day of storage, whereas control sample got visual score on $7^{\text {th }}$ day at $27^{\circ} \mathrm{C}$. Overall banana treated with hexanal vapour showed very good visual appearance even up to $15^{\text {th }} \mathrm{d}$ compared to control sample at room temperature. Hence, it was concluded that hexanal vapour could maintain a better appearance and visual quality for at least 9 to 10 days more than fruits without any treatment. Based on the following criteria namely the shelf life, PLW, firmness, respiration rate, TSS and peel colour among the treatment, $1200 \mathrm{ppm}$ for $2 \mathrm{~h}$ exposure time was found to be best.

It is concluded that the use of active concentrations of $1200 \mathrm{ppm}$ of hexanal vapour were effective to cause an increase in the shelf life of the partially ripened fruits in terms of delayed evolution of the color of the skin and maintaining the consistency of the pulp. Partially ripened banana exposed to hexanal vapour exhibited low TSS, respiration rate and weight loss as compared to control fruits. Thus, this investigation indicated that hexanal vapour is a potent ethylene action inhibitor and the application of the hexanal vapour is a suitable technology for ripening inhibition and quality maintenance of partially ripened banana fruits related to expanded marketability.

\section{References}

Agricultural Statistics 2014-15

Coello, G., Sanchez, M.T. and Torralbo, F. J.
2003. Effect of treatment with 1- MCP on tomato Alimentaria, 342: 67-70.

Dole, Banana colour chart in Quality Chain, Dole Packaged Foods Europe, SAS.

Fan, L., J. Song, R.M. Beaudry and P.D. Hildebrand. 2006. Effect of hexanal vapor on spore viability of Penicillium expansum, Lesion Development on whole apples and fruit volatile biosynthesis. Journal of Food Science, 71(3):M105-M109

Fan, X., Argenta, L. and Mattheis, J. 2000. Inhibition of ethylene action by 1methylcyclopropene prolongs storage life of apricots. Postharvest Biol. and Technol. 20(2): 135-142

Feng, X., Apelbaum, A., Sisler, E.C. and Goren, R. 2000. Control of ethylene responses in avocado fruit with 1methylcyclopropene. Postharvest Biol. and Technol. 20(2):143-150.

Food and Agricultural Organization of the United Nations. 2013.

Golding, J, Shearer, D., McGlasson, W. and Wyllie, S. 1999. Relationships between respiration, ethylene, and aroma production in ripening banana. Journal of agricultural and food chemistry, 47(4): 1646-1651.

Golding, J.B, Shearer, S., Wyllie, S.G. and Mc Glasson, W.B. 1998. Application of 1-MCP and propylene to identify ethylene-dependent ripening processes in mature banana fruit. Postharvest Biol. Technol. 14: 87-98.

Harris, D.R, Seberry, J.A., Wills, R.B.H. and Spohr, L.J. 2000. Effect of fruit maturity on efficiency of 1methylcyclopropene to delay the ripening of bananas. Postharvest Biol. Technol. 20: 303-308.

Hershkovitz, V., Saguy, S.I. and Pesis, E. 2005. Postharvest application of 1-MCP to improve the quality of various avocado cultivars. Postharvest Biol. and Technol., 37(3): 252-264. 
Jayanty, S.S., Canoles, M. and Beaudry, R.M. 2004. Concentration dependence of 'Red chief Delicious' apple fruit softening and chlorophyll fluorescence to repeated doses of 1methylcyclopropene. J. Am. Soc. Hortic. Sci. 129: 760- 765.

Jeong, J., Huber, D.J., and Sargent, S.A. 2002. Influence of 1methylcyclopropene (1-MCP) on ripening and cell-wall matrix polysaccharides of avocado fruit. Postharvest Biol. and Technol. 25 (3): 241-256.

Jiang, Y. and Joyce, D.C. 2003. Softening response of 1- methylcyclopropenetreated banana fruit to high oxygen atmospheres. Plant Growth Regulation, 41 (3): 225-229.

Krammes, J.G, Megguer, C.A., Argenta, L.C., Amarante, C.V.T. and Grossi, D. 2003. Uso do 1-metilciclopropeno para retarder a maturacao de tomate. Hortic Bras, 21: 611-614.

Lohani, S., Trivedi, P.K. and Nath, P. 2004. Changes in activities of cell wall hydrolyses during ethylene-induced ripening in banana: effect of 1-MCP, ABA and IAA. Post-harvest Biol. Technol. 31: 119-126.

Manenoi, A, Bayogan, E.R., Thumdee, S and Paull, R.E. 2007.Utility of 1methylcyclopropene as a papaya postharvest treatment. Postharvest Biol. Technol., 44:55-62.

Mir, N., Canoles, M., Beaudry, R., Baldwin, E. and Pal Mehla, C. 2004. Inhibiting tomato ripening with 1methylcyclopropene. J. Am. Soc. Hortic. Sci. 129: 112-120.

Mir, N.A., Curell, E., Khan, N., Whitaker, M. and Beaudry, R.M. 2001. Harvest maturity, storage temperature, and 1MCP application frequency alter firmness retention and chlorophyll fluorescence of 'Red chief Delicious' apples. J. Am. Soc. Hortic. Sci. 126: 618-624.

Nanda, SK, Vishwakarma, RK, Bathla, HVL, Rai, Anil, Chandra, P (2012) Project Report on Harvest and Post-Harvest Losses of Major Crops and Livestock Produce in India, All India Coordinated Research Project on Post-Harvest Technology (ICAR), Ludhiana, Punjab, India.

Opiyo, A.M. and Ying, T.J. 2005. The effects of 1- methylcyclopropene treatment on the shelf life and quality of cherry tomato (Lycopersicon esculentum var. cerasiforme) fruit. Int. J. Food Sci. Technol. 40: 665-673.

Paliyath, G. and J. Subramanian. 2008. Phospholipase D inhibition technology for enhancing shelf life and quality In: Postharvest biology and technology of fruits, vegetables and flowers ed. by Paliyath, G., D.P. Murr, A.K. Handa and S. Lurie. Published by Wileyblackwell, USA. Pp. No.: 240-245.

Paliyath, G., Murr, D.P., Handa, A., and Lurie, S. Eds., 2008. Post-harvest Biology and Technology of Fruits, Vegetables and Flowers. WileyBlackwell, IA, 240-245.

Pathak, N, Asif, M.H., Dhawan, P., Srivastav, M.K. and Nath, P. 2003. Expression and activities of ethylene biosynthesis enzymes during ripening of banana fruits and effect of 1-MCP treatment. Plant Growth Regul. 40: 11-19.

Pelayo, C., Vilas-Boas, E.V.D., Benichou, M. and Kader, A.A.2003. Variability in responses of partially ripe bananas to 1methylcyclopropene. Postharvest Biol Technol. 28: 75-85.

Ranganna, S. 1991. Handbook of analysis and quality control for fruit and vegetable products. Tata McGraw-Hill Education, 920-933.

Shiga, T.M., Fabi, P., Olivera do Nascimento, J.R., Petkowicz, C.L.O., Vriesmann, 
L.C., Lajolo, F.M. and Cordenunsi, B.R. 2009. Changes in cell wall composition associated to the softening of ripening papaya: Evidence of extensive solubilization of large molecular mass galacturonides. J. Agric. Fd. Chem, 57:7064-7071.

Sisler, E.C. and Serek, E. 1997. Inhibitors of ethylene responses in plants at the receptor level: Recent advances. Physiol. Plant.100: 577-582.

Song, J., R. Leepipattanawit, W. Deng and R.M. Beaudry. 1996. Hexanal vapor is a natural, metabolizable fungicide:
Inhibition of fungal activity and enhancement of aroma biosynthesis in apple slices. J.Amer.Soc.Hort.Sci, 121(5): 937-942.

Vilas-Boas, E.V.D.B. and Kader, A.A. 2006. Effect of atmospheric modification, 1MCP and chemicals on quality of freshcut banana. Postharvest Biol. and Technol. 39 (2):155-162.

Wills, R.B.H. and Ku, V.V.V. 2002. Use of 1MCP to extend the time to ripen of green tomatoes and postharvest life of ripe tomatoes. Postharvest Biol. Technol. 26: 85-90.

\section{How to cite this article:}

Ashwini, T., S. Ganapathy, K.S. Subramanian, C. Indu Rani and Guru Meenakshi, G. 2018. Effect of Hexanal Vapour on Postharvest Quality and Shelf Life of Banana var. Grand Naine. Int.J.Curr.Microbiol.App.Sci. 7(02): 2441-2450. doi: https://doi.org/10.20546/ijcmas.2018.702.297 